\title{
Influence of food system conditions on $N$-acyl-L-homoserine lactones production by Aeromonas spp.
}

\author{
M.S. Medina-Martínez ${ }^{\mathrm{a}, \mathrm{b}}, \mathrm{M}$. Uyttendaele ${ }^{\mathrm{a}, *}, \mathrm{~V}$. Demolder ${ }^{\mathrm{a}}$, J. Debevere ${ }^{\mathrm{a}}$ \\ a Laboratory of Food Microbiologv and Fond Presenation, Ghent University - UGent, Coupure Links, 653, B-9000 Ghent, Belgium \\ - Cátedra de Microbiología de Alimentos, Facultad de Farmacia, Universidad Central de Venezucla. Apartado A0109 Caracas 1040 A, Venezuela
}

\begin{abstract}
Eleven of 13 Aeromonas strains were shown to produce AHLs. Results of TLC showed that $V$-butanoyl-L-homoserine lactone (C4-HSL) was the main AHL produced in LB medium at $30^{\circ} \mathrm{C}$. The influence of different carbon sources, temperature, $\mathrm{pH}$ values and salt concentrations on $\mathrm{AHI}$. production was determined in eight A. hydrophila and one A. caviae strain. Additionally a quantitative study of C4-HSL production by $A$. hydrophila strain 519 under different conditions was performed. Positive results were found in the AHIL induction assay for some Acromonas strains in cultures in $\mathrm{LB}$ agar incubated at $12{ }^{\circ} \mathrm{C}$ after $72--96 \mathrm{~h}$. The induction of the sensor strains by Aeromonas spp. occurrcd in LB medium supplemented with all carbon sources in a concentration of $0.5 \%$. The production of C4-HSL by $A$. hydrophila 519 was found until $3.5 \%(\mathrm{w} / \mathrm{v})$ of NaCl. For pHs close to the neutrality the C4-HSL production by A. hydrophila was cvident after 24-48 h of incubation. A. hydrophila 519 produced C4-HSL under anaerobic conditions. Also, the AHI production by Aeromonas strains was studied in simulate agar of shrimp, fish and some vegetables. The production of AHLs was evident by almost all the test strains in shrimp simulated agar. In fish agar only for one of three fish species tested. positive resulis were found. Induction assay in vegetables simulated agar showed principally negative results, probably because of the presence of inhibitory compounds in these vegelables.

(3) 2006 Elsevier B.V. All rights reserved.
\end{abstract}

Keywords: Aeromonas; Quonum scnsing; $N$-acyl-L-holnoserine laclonc; Induction assay; Food systems

\section{Introduction}

Aeromonas spp. are oxidase and catalase positive Gram negative rods belonging to the family Vibrionaceae. Aquatic environment is the principal ecosystem of these mictoorganisms, and they have been found in unprocessed water (Hornández. et al., 1997) and raw foods such as seafoods (fish, shrimp), poultry, meat, fresh vegetables (Neyts et al., 2000; CastroEscarpulli ct al., 2003).

Aeromonas spp. have optimum growth temperature ranging from $22{ }^{\circ} \mathrm{C}$ to $28^{\circ} \mathrm{C}$ and $\mathrm{pH}$ limits range from 5.2 to 9.8 . The growth of Aeromonas spp. is optimal in 1-2\% NaCl, however some strains may tolerate concentrations up to $5 \% \mathrm{NaCl}$ under otherwise ideal conditions (Blair ct al., 1999). Important characteristics of these microorganisms are the capacity to grow at

\footnotetext{
"This paper was presented at the 19th International ICFM1H Symposium, Food Micro 2004, Potorož Slovenia, 12-16 September 2004.

* Corresponding author. Tel.: +329 26461 78; fax: +329225 5510

E-mail address: Miekc.Uytteudacle(aUGent.be (M. Uyttendacle).
}

low temperatures and under anaerobic conditions which may account for the presence of elevated numbers of Aeromonas in fresh raw foods, with a prolonged shelf life under refrigeration temperature (Kirov, 2001).

Members of Aeromonas genus have been described as opportunistic pathogens which produce infections and gastroenteritis. Children, elderly and immunocompromised patients are the most affected populations (Kuijper et al., 1989). From this genus strains belong to the species $A$. hydrophila, $A$. caviae and $A$. veronii biovar sohria have been associated with gastrointestinal disease (Kirov, 1993; Janda, 1993).

Many bacteria are able to regulate the expression of phenotypic characteristics as a function of cell density, which is called quorum sensing (Milicr and Bassler, 2001). This system uses a signal molecule which is produced and released by the cell. When the concentration of the signal molecule reaches a limit (dense population), regulation in the expression of certain genes occurs. In general, the Gram negative bacteria produce $\mathrm{N}$-acyl-Lhomoserine lactone (AHL) like signal molecules in the cell to cell communication system (Whitehead et al., 2001). The 
components involved in AHL-based quorum sensing systens of the lux-homologous family have been cited by (rram et al. (2002) and the molecular bases of quorum sensing system has been described (Miller and Bassler, 2001; Schauder and Bassier, 2001; Whitehead et al., 2001).

Bacteria use quonum sensing systens to regulate several physinlogical functions such as symbiosis, virulence, motility, sporulation, biofilm formation, etc. (Winson et al., 1995; Davies et al., 1998: Lindun et al., 1998). Lynch et al. (2002) showed evidence that supports the role of AHL-dependent quorum sensing in A. hydrophila biofilm development. The identification of AHL and the cognate LuxRI homologs AhyRI from A. hydrophila and A. salmonicida were reported by Swift ct al. (1997). The regulation of exoprotease production by AHL quorum sensing system in Aeromonas hydrophila was studied by Swift et al. (1999).

Compounds present in the food matrix and the storage cnvironment could influence the production of AHLs. Environmental conditions may affect the AHL production, and it is possible that in the presence of quorum (dense population), environmental factors could affect the accumulation of AHL (Fuqua et al., 2001). Fuqua et al. (2001) explained the dynamics of AHLs accumulation. The $\mathrm{pH}$ is an important factor that can affect the stability of AHLs. In alkaline conditions, most AHLs are unstable and a degradation of these molecules will occur (Fuqua et al., 2001). The effect of several conditions on AHLs produced by two Enterobacteriaceae isolated from fish was studied by Ravn et al. (2002) who found the production of the same type of AHIs under all conditions tested and similar amounts produced in almost all the conditions studied, however the anthors reported that the AHIs produced become unstable under alkaline condition ( $\mathrm{pH}>7.5$ ). Grans et al. (1999) studied the production of AHLs by 154 psychrotrophic Enterobacteriaceae strains, isolated from cold-smoked salmon or vacuumpacked chilled meat, finding production of 3-oxo- $\mathrm{N}$-hexanoyl homnserine lactone (3-0xo-C6-HSL) and some analogue molecules by 116 of them. These authors reported the production of detectable amounts of AHL when cuttured at $5{ }^{\circ} \mathrm{C}$ in both LB broth and defined medium supplemented with $4 \%(\mathrm{w} / \mathrm{v}) \mathrm{NaCl}$ at densities of $10^{6} \mathrm{CFU} / \mathrm{g}$. They aiso reported AHLs production in cold-smoked salmon stored at $5{ }^{\circ} \mathrm{C}$ under $\mathrm{N}_{2}$ atmosphere.

The goal of this study was to deternine the production of AHL by $A$. hydrophila and $A$. caviae strains and to evaluate the influence of environmental factors on ATL production. Information about the effect of some intrinsic and extrinsic conditions typically encountered in a fond system let to understand the dynamic of AHL production by these pathogens in fonds.

\section{Materials and methods}

\subsection{AHLs production}

\subsubsection{Strains and culture conditions}

Sensor strains were cultured in I.B medium (Difco, Le Pont de Claix, France) solidified with $1.2 \%$ agar and supplemented with appropriate antibiotic (in case of Agrobacterium tumefaciens NT1 gentamycin $50 \mu \mathrm{g} / \mathrm{ml}$, (Sigma-Aldrich, Irvine, UK); in case of Chromobacterium violaceum CV026 kanamycine $20 \mathrm{\mu g} / \mathrm{ml}$ (Sigma-Aldrich). The Aeromonas strains restcd for their AHL production were grown in LB medium solidified with $1.2 \%$ agar. All the strains were incubated at $30^{\circ} \mathrm{C}$ for $24 \mathrm{~h}$. The source of each strain is presented Table 1.

\subsection{Screening of AHL production by Aeromonas: induction assay in solid media}

Aeromonas strains were tested using the induction method in solid system described by Ravn et al. (2001). Three different sensor systems were used to screen for AHL production, which include Agrobacterium tumefaciens NT1 which carries a plasmid pZLR4 and produces a bluc color from the hydrolysis of the 5bromo-4-chloro-3-indoyl- $\beta$-D-galactopyranoside (X-Gal) in the medium by the $\beta$-galactosidase expressed from traG:lac $Z$ riporter fusion when induced by particular AHLs (Cha et al., 1998; Ravn et al., 2001); Chromobacterium violaceum strain CV026 with the LuxR homologue, CviR, which regulates the production of a purple pigment when induced by particular AHI.s (McClean e1 al. 1997; Ravu et al., 2001); and the inhibition of CviR of Chromobacterium violaceum by long chained AHLs resulting in a lack of pigment when compared to the control (McClean et al., 1997; Ravn et al., 2001). Each strain was streaked onto LB medium in parallel to the sensor strain. In the assay with $A$. tumefaciens NTi the L.B medium was supplemented with $50 \mu \mathrm{g} /$

Table 1

Bacterial strains

\begin{tabular}{|c|c|c|}
\hline Strain & Isolated from & Source or reference \\
\hline $\begin{array}{l}\text { Chromoburterium } \\
\text { violaceum CV026 }\end{array}$ & & Rasno c1 al., 200! \\
\hline $\begin{array}{l}\text { Agrobacterium } \\
\text { tumefaciens NTI (FZLR4) }\end{array}$ & & Ravin et al.. 2001 \\
\hline Serratia liquefaciens MGi & & Ravn $\mathrm{cl}$ al, $2 \mathrm{COI}$ \\
\hline Pseudomonas aeruginosa POI & & Ravn cl al., 2001 \\
\hline Aeromonas hydrophila 064 & Faeces & $\begin{array}{l}\text { BCCM }^{\mathrm{TM}} \\
\text { collection (LMG 377I) }\end{array}$ \\
\hline Aeromonas hydrophila 566 & Facces & $\begin{array}{l}\text { ВСCM } \\
\text { collection (LMG 13662) }\end{array}$ \\
\hline Aeromonas hydrophila 569 & Facces & $\begin{array}{l}\text { BCCM } \\
\text { collection (LMG 13442) }\end{array}$ \\
\hline Aeromonas hydrophilat 519 & Mcat & LFMFP \\
\hline Aeromonas hydrophila 489 & Fish (Whiting) & LFMFP \\
\hline Aeromonas hydrophila 497 & Meat (Beef stenk) & LFMFP \\
\hline Aeromonas hydrophila 495 & Fish (Salmon) & LFMFP \\
\hline Aerumonas hydrophila 514 & Bacon & LFMFP \\
\hline Aeromonas caviae HG4 438 & Bean & LFMFP \\
\hline Aeromonas caviae 574 & Faeces & $\begin{array}{l}\text { BCCM }^{\mathrm{TM}} \\
\text { collection (LMG 13680) }\end{array}$ \\
\hline $\begin{array}{c}\text { Aeromonas cavine } \\
\text { complex } 445\end{array}$ & Vegetablc & LFMFP \\
\hline $\begin{array}{l}\text { Acromonas } \\
\text { caviae HG5B } 429\end{array}$ & Vegetable & LFMFP \\
\hline Aeromonas caviae 70 & $\begin{array}{l}\text { Epizootic of young } \\
\text { guinea pigs }\end{array}$ & $\begin{array}{l}\text { BCCM }^{\mathrm{TM}} \\
\text { collection (LMG 3775) }\end{array}$ \\
\hline
\end{tabular}

$\mathrm{BCCM}^{\mathrm{T} M}$ : Belgian Co-ordinated Collection of Micro-organisms. LMG: Laboratory of Microbiology, Ghent University.

LFMFP: I aboratory of Food Microbiology and Food Preservation, Ghent University. 
ml X-Gal (Promega, Madison, USA). The production of long chained AHLs was detected by inhibition of the induced C. violaceum in L.B agar plates supplemented with $500 \mathrm{nM} \mathrm{N}$ hexanoyl-L-homoserine lactone (C6-HSL) (Biochemika, SigmaAldrich). As positive controls Serratia liquefaciens MG1 and Pseudomonas aeruginosa POl (Ravn ct al., 2001) were used in the induction assay with $C$. violaceum and $A$. tumefaciens respectively. For the inhibition of induced $C$. violaceum, $P$. aeruginosa $\mathrm{PO}$ l was used as positive control. As a negative control, $P$. aeruginosa PO1 was used for $C$. violaceum induction. For the inhibition of induced $C$. violaceum and induction assay with $A$. tumefaciens the monitor strains themselves were used as negative controls,

\subsection{Determination of AHL type produced by Aeromonas: TLC}

The AHL types produced by the Aeromonas test strain were determined by extractions with ethyl acetate acidified and thin layer chromatography as is described by Ravn et al. (2001).

TLC was performed in a $C_{18}$ TLC plate (TLC aluminium sheets $20 \times 20 \mathrm{~cm}^{2}, \mathrm{RP}-18 \mathrm{~F}_{254} \mathrm{~S}, 1.05559$ ) (MERCK, Darmstadt, Germany); the plates were cut of $20 \times 10 \mathrm{~cm}^{2}$ and between 10 and $100 \mu \mathrm{l}$ of each extract or synthetic standard was applied. The chromatoplate was developed in $200 \mathrm{ml}$ methanol-water phase $(60: 40)$ for approximately $2 \mathrm{~h}$. The TLC plate was allowed to dry for at least $10 \mathrm{~min}$ while a top layer agar was prepared using either $C$. violaceum CV026 or A. tumefaciens NT1. For this, a preculture was done in LB mediun and incubated for $24 \mathrm{~h}$ at $30^{\circ} \mathrm{C}$, and $1 \mathrm{ml}$ of it was taken to inoculate $50 \mathrm{ml}$ of LB medium. The culture was grown for $24 \mathrm{~h}$ at $30^{\circ} \mathrm{C}$ and was mixed with either $100 \mathrm{ml}$ of LB agar (1.6\% agar) in case of $C$ violaceum or ABT agar (1.6\% agar) (Ravn et al. 2001 ) in case of $A$. tumefaciens which was previously melted and maintained at $46-48{ }^{\circ} \mathrm{C}$. Each medium was supplemented with the respective antibiotic as described before and the ABTagar for $A$. tumefaciens was mixed with $\mathrm{X}-\mathrm{Gal}(50 \mu \mathrm{g} / \mathrm{ml})$. The synthetic standards used included $N$-butanoyl-L homoserine lactone (C4-HSL) (Biochenika, Sigma-Aldrich), $\mathrm{N}$ hexanoyl-L homoserine lactone (C6-HSL) (Biochemika, Sigma Aldrich), N-octanoyl-L homoserine lactone (C8-HSL) (Biochemika, Sigma-Aidrich), 3-oxo-N-hexanoyl-L homoserine lactone (3-oxo-C6-HSL) (Sigma-Aldrich).

\subsection{Determination of quantities of C4-HSL produced by Aeromonas: agar well diffusion assay}

The amount of C4-HSL produced by the Aeromonas spp. test strains was determined using an agar well diffusion assay method as described by Ravn et al. (2001). The ethyl acetate extracts, as described before for TIC analysis, were used and the agar plates were prepared with $C$. violaceum as is described before for TLCtop layer agar. The agar was poured in $20 \mathrm{ml} /$ plate portions, and $60 \mu 1$ of each extract or C4-HSL synthetic standard added into wells $(7 \mathrm{~mm})$ punched in the middle of the agar. The plates were incubated for $24 \mathrm{~h}$ at $30^{\circ} \mathrm{C}$ and the diameter of the C4-HSL induced zone around the wells (Fig. 1) was determined with a vernier caliper. The amount of C4-HSL (nmol/10 ml culture) was

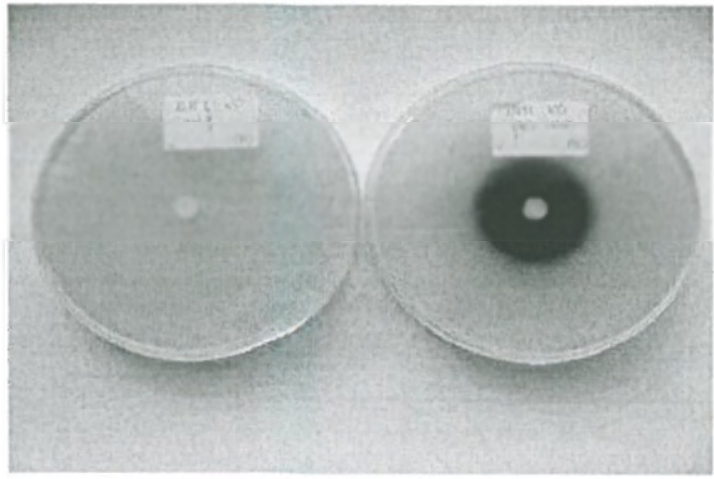

Fig. 1. Agar wcll diffusion assay with $C$. violaceum as sensor strain. Right: positive control (C4-HSL synthetic standard in ethyl acelate; $120 \mathrm{nmol}$ ). Left: negarive conirol (cthyl acclate).

calculated using a calibration curve previously set up using a synthetic C4-HSL standard.

\subsection{Effect of several conditions on C4-HSL production by} Aeromonas in solid media

The influence of several conditions: carbon source, $\mathrm{NaCl}, \mathrm{pH}$ and ternperature (Table 2) normally found in foods associated with Aeromonas spp., on the C4-HSI, production by eight $A$. hydrophila and one $A$. caviae strain was evaluated. For this, the induction assay in solid media (LB medium) was used with $C$. violaceum and $A$. lumefaciens as sensor strains. The influence of different environmental conditions on C4-HSL production was studied after $24,48,72$ and $96 \mathrm{~h}$ of incubation. For study at different $\mathrm{pHs}$, the LB medium was acidified with $\mathrm{HCl}(1 \mathrm{~N})$.

\subsection{Effect of conditions on C4-HSL production by $A$ hydrophila strain 519 in broth}

A study of C4-HSL production by Aeromonas hydrophila undet different conditions of $\mathrm{pH}, \mathrm{NaCl}$ and anaerobic conditions was performed in liquid media. For these, the strain $A$. hydrophila 519 previously checked as positive to C4-HSL was chosen. A preculture was done in LB medium and incubated at $30^{\circ} \mathrm{C}$ during $24 \mathrm{~h}$. From this preculture, three serial dilutions were prepared in PPS ( $1 \mathrm{~g} / 1$ peptone, $8.5 \mathrm{~g} / 1 \mathrm{NaCl}$ ) and $100 \mu \mathrm{l}$ of the last dilution was used to inoculate $100 \mathrm{ml}$ of fresh LB medium in order to obtain an initial level of ca. $10^{3} \mathrm{CFU} / \mathrm{ml}$. After incuhation, samples were withdrawn for determination of viable cell counts as well as for determination of C4-HSL. The method of extraction with acidified ethyl acetate and the quantification of C4-HSI using the agar well diffusion assay method was used as described before. The conditions used were $\mathrm{NaCl}$ concentration, and $\mathrm{pHs}$ as shown in Tahle 3. The anaerobic condition (<1\% oxygen and $9-13 \%$ carbon dioxide) was created in a jar with anaerobic system (AnaeroGen ${ }^{\mathrm{TM}}$ Oxoid Limited, Basingstoke, Hampshire, England).

\subsection{Induction assay in food simulate agar plates}

The induction assay with $C$. violaceum and $A$. tumefaciens was done on a simulate agar for vegetables and seafoods in order to 
Table 2

Induction assay to $A$. hivdrophlla and $A$. caviae strains under differenl conditions after 96 h of incubation

\begin{tabular}{|c|c|c|c|c|c|c|c|c|c|c|c|c|c|c|c|c|c|c|}
\hline \multirow{4}{*}{$\begin{array}{l}\text { Growth } \\
\text { conditions }\end{array}$} & \multicolumn{16}{|c|}{ Aeromonas hydrophila strains } & \multirow{2}{*}{\multicolumn{2}{|c|}{$\frac{\text { A. caviae }}{438}$}} \\
\hline & \multicolumn{2}{|c|}{064} & \multicolumn{2}{|l|}{566} & \multicolumn{2}{|l|}{569} & \multicolumn{2}{|l|}{519} & \multicolumn{2}{|l|}{489} & \multicolumn{2}{|l|}{497} & \multicolumn{2}{|l|}{495} & \multicolumn{2}{|l|}{514} & & \\
\hline & \multicolumn{2}{|c|}{$\begin{array}{l}\text { Monilor } \\
\text { system }\end{array}$} & \multicolumn{2}{|c|}{$\begin{array}{l}\text { Monitor } \\
\text { system }\end{array}$} & \multicolumn{2}{|c|}{$\begin{array}{l}\text { Monitor } \\
\text { system }\end{array}$} & \multicolumn{2}{|c|}{$\begin{array}{l}\text { Monitor } \\
\text { system }\end{array}$} & \multicolumn{2}{|c|}{$\begin{array}{l}\text { Monilor } \\
\text { system }\end{array}$} & \multicolumn{2}{|c|}{$\begin{array}{l}\text { Monilor } \\
\text { system }\end{array}$} & \multicolumn{2}{|c|}{$\begin{array}{l}\text { Monitor } \\
\text { system }\end{array}$} & \multicolumn{2}{|c|}{$\begin{array}{l}\text { Monitor } \\
\text { system }\end{array}$} & \multicolumn{2}{|c|}{$\begin{array}{l}\text { Monitor } \\
\text { system }\end{array}$} \\
\hline & C.v & A. $\mathrm{t}$. & C. $v$. & A. $\mathrm{t}$ & C.v. & A. t. & C.v. & A. $\mathrm{t}$ & C.v. & A. t. & C.v. & A. $\mathrm{t}$. & C.v. & A. 1 & C.v. & A. t. & C.v. & A. t. \\
\hline \multicolumn{19}{|c|}{ Temperature" } \\
\hline $10^{\circ} \mathrm{C}$ & - & - & + & - & - & - & - & - & + & - & - & - & + & - & - & - & - & - \\
\hline $12^{\circ} \mathrm{C}$ & - & - & + & - & ++ & - & + & - & $H$ & - & ++ & - & $H$ & - & + & - & + & ++ \\
\hline $22^{\circ} \mathrm{C}$ & ++ & - & ++ & + & ++ & ++ & ++ & + & ++ & + & ++ & + & ++ & + & $1+$ & + & + & ++ \\
\hline $30^{\circ} \mathrm{C}$ & ++ & $+t$ & ++ & ++ & ++ & ++ & $H$ & ++ & ++ & ++ & ++ & ++ & ++ & ++ & $t+$ & ++ & ++ & ++ \\
\hline $37^{\circ} \mathrm{C}$ & - & tw & & $1+$ & - & $+t$ & - & $+\cdot+$ & -1. & ++ & + & $H$ & - & +++ & - & ++ & - & $1+$ \\
\hline \multicolumn{19}{|l|}{$p H$} \\
\hline 5.0 & + & - & ++ & - & +1 & - & ++ & - & ++ & - & ++ & + & $H$ & + & $+t$ & - & + & ++ \\
\hline 5.5 & + & - & ++ & + & ++ & - & +1 & + & +4 & + & ++ & + & + & ++ & $t+$ & + & ++ & ++ \\
\hline 6.0 & ++ & +1 & + & +1 & ++ & $+t$ & ++ & ++ & ++ & ++ & +1 & ++ & $4+$ & ++ & $+t$ & $+t$ & $+t$ & $\leftrightarrow$ \\
\hline 6.5 & ++ & ++ & $H$ & + & ++ & ++ & ++ & ++ & ++ & ++ & ++ & H & ++ & ++ & ++ & $+H$ & ++ & + \\
\hline 7.0 & +4 & +1 & $1+t$ & +1 & $1+t$ & $+x$ & $+\cdots$ & +1 & t+ & ++ & +1 & $-1+$ & +++ & +++ & $+\psi$ & +1 & $1+$ & $+-t$ \\
\hline \multicolumn{19}{|l|}{$[\mathrm{NaCl}]^{b}$} \\
\hline 0.5 & ++ & + & ++ & + & ++ & ++ & ++ & + & ++ & + & ++ & + & $H$ & ++ & $+\cdot+$ & + & ++ & ++ \\
\hline $1 \%$ & ++ & $+t$ & +1 & ++ & + & ++ & ++ & + & ++ & ++ & ++ & $++r$ & +1 & $H$ & ++ & + & ++ & ++ \\
\hline $1.5 \%$ & ++ & $+t$ & ++ & ++ & ++ & $+t$ & + & $+t$ & ++ & + & - & + & ++ & ++ & ++ & + & + & +1 \\
\hline $2 \%$ & - & $+t$ & - & ++ & - & + & - & ++ & - & ++ & - & ++ & - & ++ & - & ++ & - & ++ \\
\hline $2.5 \%$ & & $t+t$ & - & +4 & - & $++t$ & - & $t+$ & - & $H$ & - & $+t$ & - & +1 & & $4+i$ & - & $1+$ \\
\hline $3 \%$ & - & ++ & - & ++ & - & ++ & - & ++ & - & $H$ & - & ++ & - & ++ & - & ++ & - & $H$ \\
\hline $3.5 \%$ & - & - & - & $+H$ & - & +1 & - & - & - & - & - & - & - & -- & - & - & - & +1 \\
\hline $4 \%$ & - & - & - & - & - & - & - & - & - & - & - & - & - & - & - & - & - & - \\
\hline $4.5 \%$ & - & - & - & - & - & - & - & - & - & - & - & - & - & - & - & - & - & - \\
\hline \multicolumn{19}{|c|}{ Carbon source } \\
\hline Glucose & + & ++ & ++ & ++ & H & ++ & + & ++ & ++ & ++ & ++ & + & ++ & ++ & ++ & ++ & ++ & ++ \\
\hline Lactosc & + & - & ++ & - & ++ & - & ++ & - & ++ & - & ++ & - & t+ & - & ++ & - & +4 & - \\
\hline Mannitol & $+t$ & $t+t$ & $+t$ & ++ & $H$ & +4 & $+t$ & 州 & $1++$ & $-1+$ & $+4+$ & ++ & 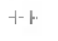 & ++ & $f+$ & $t+r$ & + & $+t$ \\
\hline Sorbilol & + & +4 & ++ & + & H & ++ & ++ & ++ & ++ & + & ++ & H & ++ & ++ & $+t$ & ++ & ++ & ++ \\
\hline Mannose & ++ & ++ & $+t$ & ++ & ++ & +4 & ++ & ++ & ++ & ++ & ++ & + & ++ & + & ++ & ++ & ++ & ++ \\
\hline
\end{tabular}

${ }^{a}$ Serratia liquefaciens (positive control) was ncgative in loc C. violaceum induclion at $10^{\circ} \mathrm{C}$ and $37^{\circ} \mathrm{C}$. $P$. aerugimosa (positive control) was negative in the $A$, tumefaciens induction at $10^{\circ} \mathrm{C}$ and $12^{\circ} \mathrm{C}, P$ aeruginosa (negative control) was positive in the induction assay with C. violaceum at $22^{\circ} \mathrm{C}$.

${ }^{\mathrm{b}}$ Serratia liquefaciens (positive control) was positive in the induclion assay wilh C. violaceum until $2 \% \mathrm{NaCl}$. $P$. aeruginose (positive control) was posilive at all NaCl concentrations in the induction assay with A. tumefaciens. C...: Chromohacterium violaceum; A.1.: Agrobacterium tumefaciens; $(+)$ weak positive; $(++)$ strong positive; $(-)$ negative.

know if the AHL can be produced at the different food compositions. For vegetables, the method described by Jacxsens et al. (2003) was followed. The vegetables were washed with cold tap water $(60 \mathrm{~s})$ and dried for $60 \mathrm{~s}$ by means of a manual kitchen centrifuge (ACIAA, Manodomestici, Italy). Then, the vegetahles were cut with a kitchen knife, and after blending in a food processor (Braun, type 4290, Kronberg, Germany) to obtain juice and pulp, the juice was centrifuged at $16,270 \times g$ during $20 \mathrm{~min}$ (Sorvall, RC-5B, Du Pont Instruments, Delaware, USA). The supcrnatant was heated for $2 \mathrm{~h}$ at $80^{\circ} \mathrm{C}$ to denature enzymes and proteins, and filtered (Retsch, $200 \mu \mathrm{m}$, Haan, Genmany). Finally the extract was nixed with $1.5 \%$ agar and autoclaved for $15 \mathrm{~min}$ at $121^{\circ} \mathrm{C}$. To simulate fish and shrimp agar, the method described by Boskou and Debcvere (1997) was followed. Briefly shrimps and three species of fish were used. Each one was divided in portions of $200 \mathrm{~g}$, mixed with $400 \mathrm{ml}$ of distilled water, and blended for $1 \mathrm{~min}$ in a lab blender (Waring Commercial, Connecticut, USA). The mix was heated in a bath for $1 \mathrm{~h}$ at $80^{\circ} \mathrm{C}$ cooled and squeezed through a bag of cheesecloth to remove the precipitate. The filtrate was centrifuged at $16,270 \times \mathrm{g}$ for $10 \mathrm{~min}$ and the supernatant was mixed with $1.5 \%$ agar and autoclaved for $15 \mathrm{~min}$ at $121{ }^{\circ} \mathrm{C}$. Of each extract the $\mathrm{pH}$ was measured in a $\mathrm{pH}$ meter (Microprocessor pH meter 763, Knick, Berlin, Germany) with an electrode (Mettler Toledo, Urdorf, Switzerland).

\section{Results and discussion}

\subsection{Detection, identification and estimation of quantities of AHLs produced by Aeromonas test strains.}

Of 13 Aeromonas strains tested, 10 strains produced response in $C$. violaceun and 11 strains caused reaction in $A$. tumefaciens, which indicates the diffusible AHL production (Table 4). The test strains did not cause inhibition of pigment production in the induced $C$. violaceum $C V 026$ system, thus indicating no production of long chain AHLs by these strains. By means of a TLC 
analysis the main AHL produced was tentatively identified as C4-HSL, according to the Rf value $(\sim 0.64)$ and the shape of the spot. A similar $\mathrm{R}_{\mathrm{f}}$ value was reported by Ravn et al. (200I) for C4HSL produced hy Serratia liquefaciens MG1. The TIC results for A. hydrophila 519 are shown in Fig. 2. The induction of A. tumefaciens by $A$. hydrophila strains was detected in spite of some authors reporting that $A$. tzmefaciens does not sense C4HSL (Shaw et al., 1997). The A. tumefaciens sensor strain may have sensed other AHLs such as C6-HSL, although C6-HSL was not detected by TLC in the Aeromonas extract. The C6-HSL standard was visualized by TLC (Fig. 2). The production of C6HSL in Aeromonas spp. was described by Swift et al. (1997) who

Table 3

C4-HSL production by .1. hydrophila 519 under the different conditions

\begin{tabular}{|c|c|c|c|}
\hline Growth conditions & Time (h) & CFU/m! & $\begin{array}{l}\text { C4-HSL } \\
\text { nmol:10 m? }\end{array}$ \\
\hline \multicolumn{4}{|l|}{$[\mathrm{NaCl}]$} \\
\hline \multirow[t]{3}{*}{$0.5 \%$} & 24 & $1.19 \times 10^{9}$ & 130 \\
\hline & 48 & $936 \times 10^{9}$ & 370 \\
\hline & 72 & $6.65 \times 10^{9}$ & 290 \\
\hline \multirow[t]{3}{*}{$1 \%$} & 24 & $1.19 \times 10^{9}$ & $<40^{a}$ \\
\hline & 48 & $1.13 \times 10^{10}$ & 260 \\
\hline & 72 & $2.79 \times 10^{9}$ & 280 \\
\hline \multirow[t]{3}{*}{$1.5 \%$} & 24 & $7.60 \times 10^{8}$ & $\mathrm{ND}$ \\
\hline & 48 & $2.53 \times 10^{9}$ & 140 \\
\hline & 72 & $1.73 \times 10^{9}$ & 240 \\
\hline \multirow[t]{3}{*}{$2 \%$} & 24 & $7.90 \times 10^{8}$ & $<40$ \\
\hline & 48 & $1.38 \times 10^{9}$ & $<40$ \\
\hline & 72 & $1.58 \times 10^{9}$ & 290 \\
\hline \multirow[t]{3}{*}{$2.5 \%$} & 24 & $4.60 \times 10^{8}$ & $<40$ \\
\hline & 48 & $4.80 \times 10^{9}$ & $<40$ \\
\hline & 72 & $7.80=10^{8}$ & 105 \\
\hline \multirow[t]{3}{*}{$3 \%$} & 24 & $7.50 \times 10^{7}$ & $<40$ \\
\hline & 48 & $1.54 \times 10^{8}$ & 120 \\
\hline & 72 & $1.59 \times 10^{8}$ & 70 \\
\hline \multirow[t]{3}{*}{$3.5 \%$} & 24 & $1.07 \times 10^{7}$ & $<40$ \\
\hline & 48 & $4,80 \times 10^{\mathrm{A}}$ & 80 \\
\hline & 72 & $1.44 \times 10^{8}$ & 80 \\
\hline \multirow[t]{3}{*}{$4 \%$} & 24 & $2.90 \times 10^{7}$ & $<40$ \\
\hline & 48 & $7.00 \times 10^{6}$ & $<40$ \\
\hline & 72 & $1.90 \times 10^{7}$ & $<40$ \\
\hline \multirow[t]{3}{*}{$4.5 \%$} & 24 & $1.00 \times 10^{4}$ & $<40$ \\
\hline & 48 & $4.90 \times 10^{7}$ & $<40$ \\
\hline & 72 & $4.00 \times 10^{6}$ & $<40$ \\
\hline \multicolumn{4}{|l|}{$p H$} \\
\hline \multirow[t]{3}{*}{6.5} & 24 & $2.50 \times 10^{9}$ & 280 \\
\hline & 48 & $3.11 \times 10^{9}$ & 310 \\
\hline & 72 & $1.72 \times 10^{9}$ & 255 \\
\hline \multirow[t]{3}{*}{6.0} & 24 & $1.60 \times 10^{9}$ & 220 \\
\hline & 48 & $4.60 \times 10^{9}$ & 310 \\
\hline & 72 & $2.11 \times 10^{9}$ & 60 \\
\hline \multirow[t]{3}{*}{5.5} & 24 & $5.20 \times 10^{6}$ & $<40$ \\
\hline & 48 & $7.80 \times 10^{\mathrm{B}}$ & $<40$ \\
\hline & 72 & $2.45 \times 10^{9}$ & 50 \\
\hline \multicolumn{4}{|l|}{ Anacrobiosis } \\
\hline & 24 & $1.16 \times 10^{9}$ & 90 \\
\hline & 48 & $2.24 \times 10^{9}$ & 185 \\
\hline & 72 & $1.51 \times 10^{9}$ & 420 \\
\hline
\end{tabular}

(Incubation lemperature $30^{\circ} \mathrm{C}$ ).

"Lower detection limit $(40$ nmol/s0 ml) of the agar wel] diffusion assay using synthetic standard C4-HSL and C. violoccum as the sensor stain. ND: not determined.
Table 4

Screcening of AHL production hy Aeromonas tesı sirains

\begin{tabular}{|c|c|c|c|}
\hline \multirow[b]{2}{*}{ Strain } & \multicolumn{3}{|c|}{ Sensor strain } \\
\hline & $\begin{aligned} & \text { C. violaceum } \text { CV026 } \\
& \text { induction }\end{aligned}$ & $\begin{array}{l}\text { A. iumefaciens NTI } \\
\text { assay }\end{array}$ & $\begin{array}{l}\text { C. violacum Cv026 } \\
\text { inhibition assay }\end{array}$ \\
\hline 864 & + & ++ & - \\
\hline 566 & ++ & ++ & - \\
\hline 569 & ++ & ++ & - \\
\hline 519 & t+ & ++ & - \\
\hline 489 & ++ & ++ & - \\
\hline 497 & $1+$ & $+t$ & - \\
\hline 495 & ++ & ++ & - \\
\hline 514 & ++ & ++ & - \\
\hline 438 & + & + & - \\
\hline 574 & - & - & - \\
\hline 445 & $+t$ & ++ & - \\
\hline 429 & - & + & - \\
\hline 70 & - & - & - \\
\hline
\end{tabular}

identified the major AHI signal purified from A. hydrophila and A. salmonicida culture supematants as C4-HSL and a second minor signal as C6-HSL with a ratio of approximately $70: 1$.

One $A$. caviae strain produced a compound with chromatographic properties (typical tale sharp and $\mathrm{R}_{f}$ value 0.57 ) corresponding to the 3-oxo-C6-HSL synthetic standard (results not shown). This is, however only a preliminary identification and must be confirmed by other methods such as high pressure liquid chromatography, mass spectrometry, nuclear magnetic resonance and infrared spectroscopy (Shaw ot al., 1997; Brelles-Mariño and Bedmar, 2001.). No former reports were found about AHL production by $A$. caviae.

According to the TLC results, C4-HSL was considered as the principal AHL produced by the tested Aeromonas strains and the major contributor to the induced areas surrounding the wells in the diffusion assay. Therefore a calibration curve with a C4-HSI, synthetic standard was set up (Fig. 3) and an estimate of the quantities of C4-HSL was calculated. The detection limit for quantification was ca. $5 \mathrm{nmol}(40 \mathrm{nmol} / 10 \mathrm{ml}$ of sterile supernatant). The amount of C4-HSL produced by $10 \mathrm{ml}$ of culture of these C4-HSL producing $A$. hydrophila (8 strains) and $A$. caviae (1 strain) after $24 \mathrm{~h}$ incubation at $30^{\circ} \mathrm{C}$ ranged from ca. 25 to ca. 200 nmol.

3.2. Effect of different conditions on AHL production by $A$. hydrophila and $A$. caviae strains in solid media

The results of the induction assay for the Aeromonas test strains under different conditions are presented in Table 2. The induction of sensor strains nccurred mainly on the optimal growth conditions. Also 8 of 9 test strains showed AHL production at $12^{\circ} \mathrm{C}$, after $96 \mathrm{~h}$ of incubation. Ravn of al. (2003) tested the influence of temperature $\left(5^{\circ} \mathrm{C}, 25^{\circ} \mathrm{C}\right)$ and other conditions on the AHI profile and production rate of a Serratia proteamaculans and an Enterobacter agglomerans strain. Both produced the same types of AHLs under all the tested conditions. A. hydrophila is able to grow in food products kept at refrigeration temperatures and evidence axists that Aeromonas species can produce virulence factors (compounds of an organism that determine its capacity to 


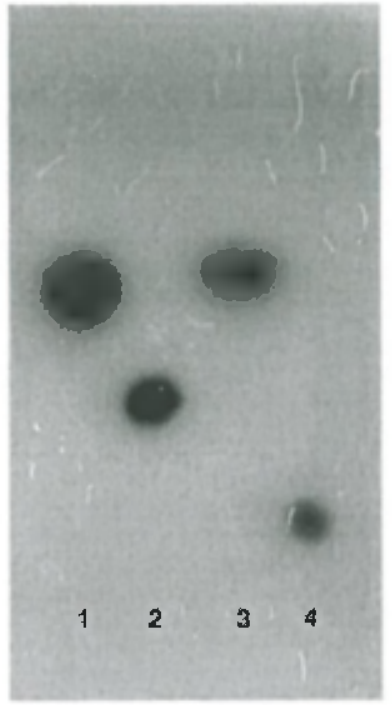

Fig. 2. Thiu layer chromatography of $A$. hydrophila 519 visualized using $C$ viola ceum CV026, 1. N-butanoyl-L-homoserine lectone (1.8 mM). $2 \mathrm{~N}$-hexanoyl-Lhomoscrinc lactone $\left(1.75 \times 10^{-2} \mathrm{mM}\right.$. 3. Aevmenhs hydrophila 519 cxiract, 4. Noctanoyl-t,-homoscrinc lactone $(0.48 \mathrm{mM})$.

cause disease) under this condition (Kirov et al., 1993; Tsai et al., 1997; González-Rodriguez et al., 200:4). The effect of different carbohydrates on AHI. production showed induction of sensor strains in LB agar supplemented with all carbon sources at a concentration of $0.5 \%$. Only in the assay with LB agar plus lactose and $\mathrm{X}-\mathrm{Gal}$ the results were negative. This is probahly due to the induced galactosidase activity which is used to split the lactose, present in excess compared to the X-Gal, in glucose and galactose; Ravn et al. (2003) reported no effect on the specific 3 oxo-C6-HSL production by a $S$. proteamaculans strain by addition or change of carbon sources.

In the induction assays under different $\mathrm{NaCl}$ concentrations, positive results with $A$. hmefaciens were observed with $3 \%$ and $3.5 \% \mathrm{NaCl}$. C. violaceum can no growth at levels higher than $2 \%$, which indicate its limited use in this assay.

This rapid screening in solid media allows having an idea about the conditions normally found in food systems in which Aeromonas sp. could produce the signal molecule. However only qualitative results (induction or not) can be obtained, and no relative differences among degrees of induction can be concluded. In addition, positive results depend upon the ability of the sensor strains to grow and express the AHI, dependent phenotype under adverse conditions. This indicates that the AHL production per se is no affected, but the detection will depend on the sensor strain used. Thereforc, initiative was taken, to determine C4-HSL quantitatively in extract of culture supernatants of Aeromonas test strains grown under different conditions commonly encountered in foods.

\section{3. Production of C4-HSL by A. hydrophila 519 in liquid media under different conditions}

Table 3 presents the results obtained for C4-HSL production by A. hydrophila 519 under different conditions. In gencral the results show a strong relation between high population levels $\left(10^{8}-10^{9} \mathrm{CFU} / \mathrm{ml}\right)$ and AHL production. Our data agree witl previous reports about AHL quorum sensing systems in bacteria such as Vibrio fischeri LuxI/LuxR bioluminescence system which were reviewed by Fuqua et al. (2001) and Miller and Bassler (2001). Under sub-optimal conditions more time of incubation was necessary in order to obtain the quorum (dense population) necessary for C4-HSL production.

\subsubsection{Sodium chloride}

At $4 \%$ and $4.5 \%(\mathrm{w} / \mathrm{v}) \mathrm{NaCl}$, no C4-HSL production was notified. This result is correlated with a low colony count (maximum of $1.9 \times 10^{7}$ and $4.0 \times 10^{6} \mathrm{CFU} / \mathrm{mi}$ respectively). In general, the higher the $\mathrm{NaCl}$ concentration (from $0.5 \%$ to $3.5 \%$ ), the lower the C4-HSL production (from ca. $370 \mathrm{nmol} / 10 \mathrm{ml}$ to $80 \mathrm{mmol} /$ $10 \mathrm{ml}$ ). C4-HSL production was detected at 1 to $3.5 \%$ only after $48-72 \mathrm{~h}$ although under these conditions cultures in L.B medium reached high numbers $\left(4.6 \times 10^{8}-4.6 \times 10^{9} \mathrm{CFU} / \mathrm{ml}\right)$ earlier without C4-HSL being detected using the agar well diffusion assay. This may be due to the high detection limit of the method. The degrce of variability between results obtained in extractions that were performed in duplicate and the fact that the measurement of the halo around the well in the diffusion assay may show some variation dependant upon the analyst, indicate the limitations of the agar well diffusion method as a reliable quantitative method for C4-HSL. Therefore, the C4-HSI, concentrations mentioned should be interpreted as an estimate of the real value. The agar well diffusion should be regarded as a semi-quantitative method rather than an exact quantitative method.

\subsection{2. $\mathrm{pH}$}

With regard to C4-HSL production at different $\mathrm{pH}$ values, $\mathrm{C4}$ HSL concentrations of ca. $310 \mathrm{mmol} / 10 \mathrm{ml}$ were found after $48 \mathrm{~h} \mathrm{of}$ incubation at $\mathrm{pH} 6$ and 6.5 . These results correlated to viable cell counts of $>10^{9} \mathrm{CF} J / \mathrm{ml}$. At pH 5.5 only after $72 \mathrm{~h}$ of incubation detectable C4-HST levels were found. which was the fime when the culture reached $9 \log \mathrm{CFU} / \mathrm{ml}$. Only acid conditions were taken up in the experimental setup as it is known that at alkaline pHs (7.5) AHLs are unstable (Fuqua et al., 2001; Ravn et al., 2003).

\subsubsection{Anaerobic conditions}

Aeromonas spp. is a facultative anaerobic microorganism, able to grow under limitation of oxygen in the environment. Detectable

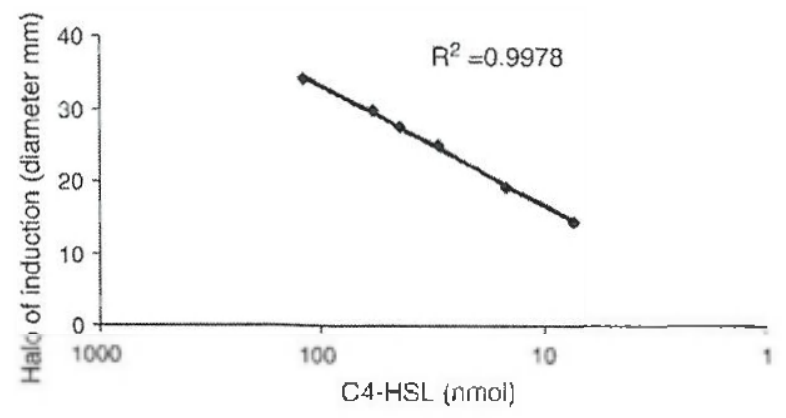

Fig. 3. Standard curve, relating diameter of induced zone in $C$. violaceum agar well diffusion assay with concentrations of synthetic C4-HSL standard. 
Table 5

lnduction assay to A.hydrophilo and $A$. caviat in simulated vegetable agars

\begin{tabular}{|c|c|c|c|c|c|c|c|c|c|c|c|c|c|c|c|c|c|c|}
\hline \multirow{4}{*}{$\begin{array}{l}\text { Simulated food agar } \\
\\
\begin{array}{l}\text { Broccoli } \\
\text { (Brassica nleracca) }\end{array}\end{array}$} & \multicolumn{16}{|c|}{ Aeromonas hydrophila strains } & \multirow{2}{*}{\multicolumn{2}{|c|}{$\frac{\text { A. caviae }}{438}$}} \\
\hline & \multicolumn{2}{|c|}{064} & \multicolumn{2}{|c|}{566} & \multicolumn{2}{|c|}{569} & \multicolumn{2}{|c|}{519} & \multicolumn{2}{|c|}{489} & \multicolumn{2}{|c|}{497} & \multicolumn{2}{|c|}{495} & \multicolumn{2}{|c|}{514} & & \\
\hline & \multicolumn{2}{|c|}{$\begin{array}{l}\text { Monitor } \\
\text { sysiem } \\
\text { C.v. A.t. }\end{array}$} & \multicolumn{2}{|c|}{$\begin{array}{l}\text { Monitor } \\
\text { sysicm } \\
\text { C.v. A.t. }\end{array}$} & \multicolumn{2}{|c|}{$\begin{array}{l}\text { Monitor } \\
\text { system } \\
\text { C.v. A. I. }\end{array}$} & \multicolumn{2}{|c|}{$\begin{array}{l}\text { Monilor } \\
\text { system } \\
\text { C.v. A. t. }\end{array}$} & \multicolumn{2}{|c|}{$\begin{array}{l}\text { Monitor } \\
\text { system } \\
\text { C.v. A. t. }\end{array}$} & \multicolumn{2}{|c|}{$\begin{array}{l}\text { Monitor } \\
\text { system } \\
\text { C.v. A. t. }\end{array}$} & \multicolumn{2}{|c|}{$\begin{array}{l}\text { Monitor } \\
\text { system } \\
\text { C.v. A. t. }\end{array}$} & \multicolumn{2}{|c|}{$\begin{array}{l}\text { Monitor } \\
\text { systern } \\
\text { C.y. A. t. }\end{array}$} & \multicolumn{2}{|c|}{$\begin{array}{l}\text { Monilor } \\
\text { system } \\
\text { C.v. A. t. }\end{array}$} \\
\hline & - & - & - & - & - & - & - & - & + & - & + & - & - & - & - & - & - & - \\
\hline $\begin{array}{l}\text { Parsley" } \\
\text { (Pctrosclinm crispus) }\end{array}$ & - & - & - & - & - & - & + & - & + & + & - & - & ++ & ++ & + & - & - & - \\
\hline Parslcy & - & - & - & - & - & - & - & - & - & - & - & - & - & - & - & - & - & - \\
\hline $\begin{array}{l}\text { Spinach } \\
\quad \text { (Spinacia oleracea) }\end{array}$ & - & - & - & - & - & - & - & +1 & $t$ & +1 & - & ++ & +1 & & + & - & - & + \\
\hline $\begin{array}{l}\text { Mixed lethec } \\
(\text { Lactuca sutiva })\end{array}$ & - & - & - & - & - & - & - & - & - & - & - & - & - & - & - & - & - & - \\
\hline $\begin{array}{l}\text { Sprouts } \\
\text { (Brassica nleraceas } \\
\text { var. gemmifera) }\end{array}$ & - & - & - & - & - & - & - & - & - & - & - & - & - & - & - & - & - & - \\
\hline
\end{tabular}

a.b Two types of parsley were used. 'Lettucc types: endive, krul, radicchio, llolo roso ( . sativa var. crispa), blonda and oak leaf lettuce (Cichorium intyhus).

C.v.: Chromohacterium violaceun; A.t.: Agrobacteriun tunefaciens; $(+)$ weak positive; $(++)$ strong positive; (-) negative.

C4-HSL levels were found under anaerobic conditions with increments 1hroughout the incubation time. Gram et al. (1999) reported the production of detectable amounts of AHL hy psychrotrophic Enterobacteraceae when cultured in pieces of salmon, which were incubated at $5{ }^{\circ} \mathrm{C}$ under $\mathrm{N}_{2}$ atmosphere, simulating the low oxygen conditions of vacuum packing. The capacity to produce AHL in anaerobic conditions and at low temperaturcs by this $A$. hydrophila strain shows that the quorum sensing system could be relevant in an Aeromonas population in foods kept under these conditions.

Quorum sensing has been described in many important Gram negative hacteria associated with foods e.g. Enterohacter, Pseudomnnas and Serratia (Gram et al., 1999: Stcidle tt al., 2002; Christensen et al., 2003). However few studies involved relevant conditions present in the food matrix and food environment. Our study is a contribution to understand the effect of some extrinsic and intrinsic parameters, present in foods related with Aeromonas hydrophila, on the production of AHL.

\subsubsection{AHL production in food simulate agar}

Aeromonas spp. have been isolated from both vegetables and seafonds (Neyts et al., 2000; Castro-Escarpulli et al., 2003). Gram et al. (2002) in a review showed positive results for the presence of AHL in bean sprouts stored at $5{ }^{\circ} \mathrm{C}$ and in fish products. The AHL induction in simulated food agars allow to know if these molecules can be produced in real food conditions. Tubles 5 and 6 show the results of AHI, induction in simulated food agar plates. Eight of nine test strains were positive in the induction assay on shrimp agar plates. Only one (Dory, Zeus fabe) of the three types of tested fishes showed positive results. These differences could be due to the instability of the AHLs at alkaline $\mathrm{pH}(\mathrm{pH}>8)$ of the agars. Shrimp and Dory fish agars had a $\mathrm{pH}$ around 7 . In vegetable agar plates, only few Aeromonas strains gave positive results for parsley, spinach and broccoli. No production of AHL was detected in the rest of vegetables tested. The $\mathrm{pH}$ values of all simulate vegetable agars were between 5.6 and 6.6 which is, as shown in Table 2, not inhibitory to C4-HSI, production.

Table 6

Induction assuy to $A$. hydrophila and $A$. caviae in simulated siminp and fish agars

\begin{tabular}{|c|c|c|c|c|c|c|c|c|c|c|c|c|c|c|c|c|c|c|}
\hline \multirow{3}{*}{$\begin{array}{l}\text { Simulated fond } \\
\text { agar }\end{array}$} & \multicolumn{16}{|c|}{ Aeromonas hydrophila strains } & \multirow{2}{*}{\multicolumn{2}{|c|}{$\frac{\text { A. caviae }}{438}$}} \\
\hline & \multirow{2}{*}{\multicolumn{2}{|c|}{$\begin{array}{l}064 \\
\text { Monitor } \\
\text { system } \\
\text { C.v.A.t. }\end{array}$}} & \multirow{2}{*}{\multicolumn{2}{|c|}{$\begin{array}{l}\frac{566}{\text { Monitor }} \\
\text { sysiem } \\
\text { C.v. A. t. }\end{array}$}} & \multicolumn{2}{|c|}{569} & \multicolumn{2}{|c|}{519} & \multicolumn{2}{|c|}{489} & \multicolumn{2}{|c|}{497} & \multicolumn{2}{|c|}{495} & \multicolumn{2}{|c|}{514} & & \\
\hline & & & & & $\begin{array}{l}\text { Mo } \\
\text { syst } \\
\text { C.v. }\end{array}$ & & $\begin{array}{l}\text { Mor } \\
\text { syst } \\
\text { C.V. }\end{array}$ & & $\begin{array}{l}\text { Mor } \\
\text { sysi } \\
\text { C.v. }\end{array}$ & & $\begin{array}{l}\text { Mo } \\
\text { sys } \\
\text { Cov }\end{array}$ & & $\begin{array}{l}\text { Mo } \\
\text { sys } \\
\text { C.v }\end{array}$ & & $\begin{array}{l}\text { Mo } \\
\text { syst } \\
\text { C.v. }\end{array}$ & & $\begin{array}{l}\text { Mo } \\
\text { syst } \\
\text { C.v. }\end{array}$ & \\
\hline Shrimp & - & - & + & ++ & ++ & ++ & ++ & H & ++ & ++ & +1 & ++ & ++ & $+t$ & ++ & ++ & ++ & + \\
\hline $\begin{array}{l}\text { Dory fish } \\
\text { (Zeus farber) }\end{array}$ & - & - & + & - & + & +++ & + & $t++$ & + & + & + & $+t$ & + & $t+k$ & + & +4 & - & - \\
\hline $\begin{array}{l}\text { Nileperch } \\
\text { (Lates niluticus) }\end{array}$ & - & - & - & - & - & - & - & - & - & - & - & - & - & - & - & - & - & - \\
\hline $\begin{array}{l}\text { Whiting } \\
\text { (Merlangius } \\
\text { Inelangus) }\end{array}$ & - & - & - & - & - & - & - & - & + & - & - & - & - & - & - & - & - & - \\
\hline
\end{tabular}

C.v: Chromohacterium violaceum; A.t: Agrobaclerium tumefaciens; $(+)$ weak positive; $(++)$ strong nositive; $(-)$ negative. 
The causes of lack of AHL production can be multiple. As noticed by visual inspection some of the test strain could not grow on some of these agars or may not have reached the population density necessary for the AHL production in detectable levels. Some compounds, naturally present in plant material, could have had some inhibitory effect on the test strains' growth. Hao et al. (1998) found that eugenol and pimento leaf extract significantly inhibited the growh of $A$. hydrophila in refrigerated cooked poultry. Inhibitory effect of essential oils and other compounds present in plant products on food-borne pathogens have been described (Cowan. 1999: Bagamboula el al., 20n4). Also some substances present in plant tissues can affect the production of AHLs. Polyphenolic compounds (widely distributed in plants) can interfere with bacterial quorum sensing (Huber et al., 2003). Therefore, our negative results show the necessity to acknowledge possible substances present in these vegetables that can inhihit responses in the sensor strain used. The present study shows that indication of AHL production in defined and controlted cultured media cannot be extrapolated to the more complex food conditions. Food simulate agars represent a closer approximation of the real food conditions. Care must be taken however in the analysis of the results of tests in complex media. False positive rcsults can also be obtained due to compounds that mimic bacterial AHLlike activities. Plant exudates from pea (Pisum sativum) secrete substances that mimic hacterial AHL-like activities in some reporter strains and affect population density-dependent behavinur in associated backeria. These compounds can stimulate AHL-regulated behaviour in some strains whilc inhibiting such hehaviours in others (Teplitski et al., 2000; Bauer and Teplitski, $2001)$. Gao et al. (2003) reported the production of at least 15 to 20 substances by the legume Medicago truncatula capable of specifically stimulating or inhibiting responses in quorum sensing reporter bacteria. In order to make decisive conclusions in assays with simulate food agars the simultaneous use of different sensor strains and appropriate medium controls are recommended.

\section{Conclusions}

It was shown that the Acromonas test strains were able to produce AHLs (in particular C4-HSL) under a variety of conditions of temperature, $\mathrm{pH}$, and $\mathrm{NaCl}$ concentrations commonly encountered in foods associated with this microorganism when multiplication to high enough numbers (dense population) was reached. Further study on the kinetics of AHI. production is being performed in our laboratory at present. The use of simulate food agar is a practical, easy and fast way to screen the production of AHL by bacterial species in conditions normally found in foods and relevant information for AHL production in food systems can quickly be obtained. Studies on the actual compounds in foods responsible for inhibition or stimulation of AHL production in Gram negative bacteria need further attention. Insight in the ability of Aeromonas strains to produce AHLs under conditions normally encountered in food products or used for food preservation, should enable a better understanding of their behaviour in food products.

\section{Acknowledgments}

We thank Dr. Lars Ravn and Dr. Lone Gram from the Department of Seafood Research, Danish Institute for Fisheries Research for providing us with sensor and contrnl strains. The authors want to thank the Consejo de Desarrollo Científico y Humanistico of Universidad Central de Venezuela for the Ph.D. scholarship of M. Medina.

\section{References}

Bagamboula, C.F. Uyttendacle, M.. Debeverc, J., 2004. Inhibitory cffect of thyme and basil essential oils, carvacrol, thymol, estragol, linalcol, and p-cymene tow ards Shigella somnet and S. flemeri. Food Microbiology 21, 33-42.

Bauer, W.D., Teplitski, M., 2001. Can plants manịulate bacterial quorum sensing? Ausiralian Joumal of Plan1 Physiology 28, 913-921.

Blair, McMahon, and Mc Dowell, 1999. htip://www.science.ulser.ac.uk/food. Boskou, G., Debevere, J., 1997. Reduction of trimethylamine oxide by Shewanella spp. under modified atmospheres in vitro. Food Microbiology $14,543-553$

Brelles-Mariñe, G., Bcdmar, E.J., 2001. Detection. purification and characterization of quorm-sensing signal molecules in plant-associated bacteria. Joumal of Biolcchnology 91, 197-209.

Castro-Fiscarpulli, G., Figucras, M.J., Aguilera-Aıtrola, G., Soler, L. FernándezRendón, E., Aparicio, G.O., Guarro, J, Chacón, M.R., 2003. Characterization of Aeromonas spp. isolated from frozen fish intended for human consumplion in Mcxico. Intemational Journal of Food Microbiology 84, 41- 49.

Cha, C., Gao, P., Chen, Y.C., Shaw, P.D., Fanand, S.K., 1998. Prnduction of acylhomoserine lactone quorum sensing signals by Gram-negative plant associated bactcria, Molecular Plant-Microbe Interactions 11, II19-1129.

Christensen, A.B., Riede1, K., Eberl, L., Fodgaard, L.R., Molin, S., Gram, L. Givskov, M, 2003. Quorum-scnsing-directed protein expression in Servatia proteanaculans B5a. Microbislogy 149, 471-483.

Cowan, M.M.1 1999. Plant producis es antimicrobial agents. Clinical Microbiology Review 12, 564-582.

Davies, D.G., Parsck, M.R., Pearson, J.P., Iglewski, B.H., Costerton, J.W., Grecuberg, E.P., 1998. The involvement of cell-to-cell signals in the development of a bacterial biofil m. Science 280, 295-298.

Fuciua, C., Parsek. M.R., Grecnberg, F.P.. 2001. Regulation of gene expression by cell to cell communication: acyl homoserine lactone quorum sensing. Annual Review of Genetics 35. 4.39-468,

Gao, M.S., Teplitski, M., Robinson. J.B., Baucr, W.D., 2003. Production of subslances by Modicago truncatula that affect bacterial quorum sensing. Molecular Plant-Microbc Intcractions 16, 827-834.

González-Rodríguez, M.-N., Santos, I.A., Otero, A., Garcia-López, M.-L., 2004. Hemolytic and protenlytic activitics of Aeromonas hwdrophila and Aeromonas veronii biovar solvia in broth and salmon extract at different temperaturcs. Joumal of Food Protection 67, 278-284.

Gram, L., Christensen, A.B., Ravn, L., Molin, S.. Givskov, M., 1999. Prnduction of acylated homoserine lactones by psychrotrophic members of the Enternbacterjaccac isolated from fcods. Applicd and Environmenlal Micmhiology 65, $3458-3463$.

Gram, I.., Ravı, L.., Rasch. M., Bruhn, J. A., Christensen, A. B., Givskov, M., 2002. Food spoilage - interactions between food spoilage bactcria. International Journal of Food Microbiology 78, 79--97.

Hao, Y.Y., Brackett, R.E., Doyle, M.P., 1998. Efficacy of plant extracts in inhibiting Aeromonas hydrophila and Lisieria monocylogenes in refrigeraled, cooked poultry. Food Micıobiology 15, 367-378.

Hemández, P., Rodrígucz, G.R., Di F.digio, D., Estrada, M., 1997. Chlorination treatment as a control of Aeromonas spp. in drinking watcr. Intemational Joumal of Environmental Health Research 7, 355-359.

Huber, B., Etcrl, L., Feuchi, W. Polster. J., 2003. Influence of polyphenols on bacterial biofilm formation and gunnm-sensing, Joumal of Biosciences 58. 879-884.

Jacxsens, L., Devlieghere, F., Ragaert, P., Vanneste, E., Debevere, I., 2003. Rclation between microbiological quality, metabolite production and sensory 
quality of equilibrium modified atmosphere packaged fresl-cut produce. International Joumal of Food Microbiology 83, 263-280.

Janda, J.M., 1991. Recent. advances in the study of the taxonomy, pathogenicity, and infectious syndromes associated with genus Aeromonas. Clinical Microbiology Revicws 4, 397-410.

Kirov, S.M., 1993. The public health significance of Aeromonas spp. in foods. International Journal of Food Microbiology 20, 179..198.

Kirov, S.M., 2001. Aeromonas and Plesiomonas species. In: Dnyle, M.P., Beuchat, L. R., Montvillc, T.T. (Fds.), Food Microbiology: Fundamentals and Fronticrs. ASM1 Press, Washington, D.C., pp. 301-327.

Kiroy, S.M., Ardestani, E.K., Hayward, L J., 1993. The growth and expression of virulence factors at refrigeration teniperature by Aeromnnas-strains isolated from foods. Intemational Joumal of Food Microbinlogy 20, 159-168.

Kuijper, E.I, Bol, P, Pecters, M.F. Steigerwalt, A.G., Zanen, H.C., Breuner, D.J., 1989. Clinical and epidemiologic aspects of members of Aeromonas DNA hybridization groups isolated from human feces. Joumal of Clinical Microbiotogy 27, 1531-1537.

Lindum, R.W. Anthoni, U., Christophersen, C., Ebcri, L., Molin, S.. Givskov, M., 1998. $\mathrm{N}$-acyl-1-homoserine lactone autoinducers control production of an extracellular lipopeptide biosurfackant required for swarming motility of Serratia liquefaciens MG1. Joumal of Bactericlogy 180, 6384-6388.

Lynch, M.J., Swift, S., Kirke, D.F., Kecvil, C.W. Dodd, C.E.R., Williams, P, 2002. The regulation of biofilm development by quorum sensing in Aeromonas hydrophila. Environmental Microbiology 4, 18-28

McClean, K.H., Winson, M.K., Fish, L., Taylor, A., Chhabra, S.R., Camara, M., Daykin, M.. Lamb, J.H., Swift, S., Bycroft, B.W., Stewalt, G.S.A.B., Williams, P., 1997. Quorum sensing and Chromobacteritm violaceum: exploitaticn of vinlacein production and inhibition for the detection of $N$-acyl homoserine lactones. Microbiology 143, 3703-37।1.

Miller, B.M., Bassier, B.L., 2001. Quorturn sensing in bacleria. Annual Revicw of Microbiology 55, 165-199.

Neyts. K., Huys, G., Uytlendacle, M., Swings, J., Debevere. J.. 2000. Incidence and identification of mesophilic Aeromonas spp. from retail foods. Letters in Applicd Microbiology 31, $359 \ldots 363$.

Ravn, L., Christensen, A.B., Molin. S., Givskov, M., Gram. I.., 2001. Methods for detecting acylatcd homoserine laclones produced by Gram-negalive bacteria and their application in studies of AHL-production kinetics. Journaj of Microbiological Methods 44, 239-251.

Ravn, L. Christensen, A.B., Molin, S, Givskev. M, Gram. I.., 2003. Influence of fond preservalion paramelers and associated microbiota on production
I'ate, profile and stability of acylatcd homoserine lactones from food-derived Enterobocteriaceas. International Journal of Food Microbiology 84. $145-156$

Shaw, P.D., Ping, G., Daly, S.L., Cha, C., Cronan Jr. J.E., Rinehart, K.L., Fanand, S.K, 1997. Detecting and characterizing $N$-acyj-homoscrinc lactone signal Inolecules hy this--Jayer chromatography. Proceedings of the National Academy of Scicnce 94, 6036-6041.

Schauder, S., Bassler, B, 2001. The languages of bacteria. Genes and Development 15, $1468-1480$

Steidle, A., Allesen-Holm, M., Ricdel, K., Herg, G., Givskov, M., Molin, S., Eberl, I... 2002. Identification and charactcrization of an $N$-acylhomoscrine lactone dependent quorum sensing system in Pseudomonas putida strain IsoF. Applied and Environmental Microbiology 68, 637J-6382.

Swift, S., Karlyshev, A.V., Fish, L., Durant, E.L., Winson, M.K., Chhabra, S.R., Williams, P.. Macintyre, S., Stewart, G.S.A.B., 1997. Quorum sensing in Aeromones hydrophila and Aeromonas salmonicida: fdentification of the LuxRl homologs AhyRI and AsaRl and their cognate N-acyl-homoscrinc lactone signal molecules. Journal of Bacieriology 179, 5271-5281.

Swift. S., Lynch, M.J., Fisl1, L., Kirkc, D.F., Tomás, J.M, Stewart, G.S.A.B., Williams, P., 1999. Quorum sensing-dependent regulation and blockade of cxoprotease production in Aeramonas hydrophila. Infection and Immunity 67. $5192-5199$

Teplitski, M., Robinson, J.B., Bater, W.D., 2000. Plants secrete substances that mimic bactcrial $N$-acyl homoserine lactone signal activities and affect population density-dependent behavior in associated bacteria. Molecular Plant-Microbc Interactions 13, 637-648.

Tsai, G.-J., Tsai, F.-C., Kong, Z.-L., 1997. Fffect of temperanure, medium compnsition, pH, salt and dissolved cxygen nri hacmolysin and cytotoxin production by Aeromonas hydrophila isolated from oyster. Intemationa Joumal of Food Microbiology 38, 111-.116

Whitchead, N.A., Barnard, A.M.L., Slater, H., Simpson, N.J.L, Salnond, G.P.C. 2001. Quorum-sensing in Gram negative hacteria. FEMS Microbiology Reviews 25, 365-404.

Winson, M.K., Camara, M., Lalifi, A., Foglino, M., Chhabra, S.R., Daykin, M., Bally, M., Chapon, V., Salmond, G.P.C., Bycroft, B., Lazdunski. A.. Stewart, G.S.A.B., William, P., 1995. Multiple $N$-Acyl-L-homoserine lactone signal molecules regulate production of virulence determinants and secondary metabolites in Pseudomonas aertiginosa. Proceedings of the National Academy ef Scicuces of the Unilcd Stalcs of Amcrica 92, 9427-9471. 